\title{
Pneumococcal endometritis with peritonitis: Case report and review of the literature
}

\author{
KI OSTROWSKA, MD, FRCPC, C ROTSTEIN, MD, FRCPC, JH THORNLEY, MD, FRCPC, \\ LA MANDELL, MD, FRCPC
}

\begin{abstract}
KI Ostrowska, C Rotstein, JH Thornley, LA Mandell. Pneumococcal endometritis with peritonitis: Case report and review of the literature. Can J Infect Dis 1991;2(4):161-164. The first case of pneumococcal endometritis with peritonitis in a woman using tampons is described. The patient responded to removal of the tampon and administration of broad spectrum antibiotics. The pathogenesis of pneumococcal endometritis and peritonitis and the potential significance of a tampon in situ are discussed.
\end{abstract}

Key Words: Endometritis, IUCD, IUD, Peritonitis, Streptococcus pneumoniae, Tampons

\section{Endométrite à pneumocoques et péritonite: Observation et recensement de la littérature}

\begin{abstract}
RESUME: On rapporte un cas d'endométrite à pneumocoques accompagné de péritonite chez une patiente utilisatrice de tampons hygiéniques. La patiente a réagi favorablement sous antibiothérapie à spectre large, et après que le tampon a été retiré. La pathogenèse de l'endométrite à pneumocoques et de la péritonite ainsi que l'importance éventuelle du tampon in situ sont examinées.
\end{abstract}

$\mathrm{P}_{\mathrm{b}}$ NEUMOCOCCAL PERITONITIS IS A FORM OF PRIMARY bacterial infection of the peritoneum occurring in children and adults $(1,2)$. It can affect both healthy and immunocompromised individuals. The former group includes prepubertal and adolescent girls (3), women in the post partum period (4-7) and women using an intrauterine contraceptive device (IUCD) (8-11). The latter group includes patients with liver cirrhosis and ascites $(12,13)$, patients with nephrotic syndrome (14), post splenectomy patients (12) and bone marrow transplant recipients (15). This paper presents a case of pneumococcal endometritis with peritonitis diagnosed clinically in a patient using tampons.

\section{CASE PRESENTATION}

A 22-year-old female university student was admitted to the hospital in November 1988 with a $12 \mathrm{~h}$ history of lower abdominal pain. The pain was associated with vomiting, diarrhea, fever and chills of $24 \mathrm{~h}$ duration. The patient was menstruating at the time and had not changed her tampon for $6 \mathrm{~h}$. There was no dysuria, frequency, vaginal discharge or pruritus. She had a single sexual partner, with her last sexual contact being three days prior to her period. Cunnilingus was performed at that time.

The past medical history was significant for an episode of abdominal pain one year previously which necessitated admission to hospital. No for-

The Division of Infectious Diseases and the Department of Pathology. Henderson General Division of the Hamilton Civic Hospitals, McMaster University, Hamilton, Ontario

Correspondence and reprints: Dr Lionel Mandell, McMaster Medical Unit, Henderson General Hospital, 711 Concession Street, Hamilton, Ontario L8V 1C3. Telephone (416) 574-8520

Received for publication March 15, 1990. Accepted November 12, 1990 
mal diagnosis was made, and the pain resolved spontaneously within one day. Most recently, the patient had been on oral contraceptives and gave no history of drug allergy.

Physical examination on admission revealed an acutely ill white female with a temperature of $39.1^{\circ} \mathrm{C}$, blood pressure $80 / 60 \mathrm{mmHg}$, and heart rate of 120 beats/min. Physical examination was significant for a markedly tender abdomen in both lower quadrants with local rebound tenderness and guarding. Speculum examination revealed a pedunculated noninflamed polyp and a small amount of exudate pooled in the vaginal vault. Pelvic examination showed extreme tenderness on cervical movement and on bimanual palpation, but no masses were noted.

Laboratory studies revealed normal electrolytes, blood urea nitrogen, creatinine and urinalysis. Leukocytes were $14.6 \times 10^{9} / \mathrm{L}$ with $88 \%$ neutrophils and $3 \%$ band cells. Gram stain of the cervical swab demonstrated rare polymorphs and rare epithelial cells. The culture showed scanty growth of Streptococcus pneumoniae, Haemophilus influenzae and normal vaginal flora. A urine culture was negative. Pelvic ultrasound and chest $\mathrm{x}$-ray were normal. The patient was treated for suspected pelvic inflammatory disease (endometritis) and septic shock with broad spectrum antibiotics including: cloxacillin, tobramycin, metronidazole and doxycycline. She improved clinically in $48 \mathrm{~h}$ and was discharged home five days later on oral penicillin $\mathrm{V}$.

Pneumococcus found in the patient's cervix was also isolated from the blood. It proved to be Strep pneumoniae type 1. Strep pneumoniae type 34 was isolated from a throat swab of the patient's sexual partner, but $H$ influenzae was not cultured.

\section{DISCUSSION}

This is the first reported case of pneumococcal endometritis with local peritonitis in a patient using tampons. Previously, cases of pneumococcal endometritis were usually diagnosed at laparotomy or on post mortem examination in patients suspected primarily of having peritonitis with or without salpingitis. Most of the patients had no primary site of infection, except for women in the post partum period. Consequently, the present literature review focuses on pneumococcal endometritis with coexisting peritonitis.

Pneumococcal peritonitis has been described in both immunocompetent and immunodeficient children and adults (Table 1). Primary pneumococcal peritonitis with no pre-existing site of infection was commonly described in young children, mainly in prepubertal girls prior to the antibiotic era, and was associated with a mortality ap-
TABLE 1

Spectrum of patients with pneumococcal peritonitis

\begin{tabular}{|c|c|}
\hline Host defence status & Coexisting factors (number of cases) \\
\hline \multicolumn{2}{|l|}{ Immunocompetent } \\
\hline Children & $\begin{array}{l}\text { Prepubertal girls (28) } \\
\text { Adolescent girls (1) }\end{array}$ \\
\hline Adults & $\begin{array}{l}\text { Healthy (1) } \\
\text { Post partum (13) } \\
\text { Intrauterine contraceptive device (6) }\end{array}$ \\
\hline \multicolumn{2}{|c|}{ Immunocompromised } \\
\hline Children & Post necrotic cirrhosis and ascites ( $(9)$ \\
\hline Adults & $\begin{array}{l}\text { Nephrotic syndrome (12) } \\
\text { Bone marrow transplant (1) } \\
\text { Post splenectomy (1) }\end{array}$ \\
\hline
\end{tabular}

proaching $100 \%(1,16,17)$. Others described this condition in otherwise healthy adolescent girls (3), children and adults with post necrotic cirrhosis and ascites $(12,13)$, nephrotic syndrome (14), bone marrow transplant (15) and post splenectomy patients (12).

Pneumococcal peritonitis with endometritis affects young women in puerperium (4-7) and those with IUCDs (8-11). Pneumococcal infections associated with the perinatal period were often fatal in the pre-antibiotic era (Table 2). In the antibiotic era, they were described mainly in association with the use of IUCDs (Table 3).

The portal of entry for pneumococcus into the peritoneal cavity remains uncertain. Four routes of invasion have been postulated: the genital tract; transdiaphragmatic lymphatics; the gastrointestinal tract; and the bloodstream. In primary pneumococcal peritonitis affecting prepubertal girls, ascending infection via the reproductive system was suggested. However, this mode of entry fails to explain the route of infection in male patients (16). Although the respiratory and gastrointestinal tract routes are favoured by some, the bloodstream seems to be the most common pathway of invasion in the majority of cases $(1,10,16,17)$.

Local factors may enhance invasion of the endometrium by the organism. Pneumococci cannot survive the $\mathrm{pH}$ of the normal vagina, which ranges between 4.0 and 5.0. However, it has been observed that children and chronically ill and debilitated patients can have an alkaline vaginal $\mathrm{pH}$ which may contribute to spontaneous pneumococcal peritonitis in these groups (6).

Apart from local factors, general immunity also plays an important role in pneumococcal infections. Post splenectomy patients are at increased risk, as are patients with liver cirrhosis and ascites with complement and IgM deficiencies. It has been shown that such deficiencies may reduce the bactericidal and opsonic activity of ascitic fluid and serum (12). 
TABLE 2

Post partum pneumococcal peritonitis with endometritis

\begin{tabular}{|c|c|c|c|c|c|c|}
\hline Case & Author & $\begin{array}{c}\text { Age } \\
\text { (years) }\end{array}$ & Clinical circumstances & $\begin{array}{l}\text { Site of positive } \\
\text { pneumococcal } \\
\text { culture }\end{array}$ & Treatment & Outcome \\
\hline 1 & Nuckols et al (6) & 24 & $\begin{array}{l}\text { Caesarean section, lobar pneumonia, } \\
\text { septicemia, meningitis }\end{array}$ & $\begin{array}{l}\text { Lung, blood, uterus, } \\
\text { meninges, tricuspid } \\
\text { valve, venous thrombi }\end{array}$ & None & Fatal \\
\hline 2 & & 29 & $\begin{array}{l}\text { Vaginal delivery, lobar pneumonia, } \\
\text { empyema, endometritis }\end{array}$ & $\begin{array}{l}\text { Sputum, blood, } \\
\text { placenta }\end{array}$ & Antiserum & Recovery \\
\hline 4 & Finland et al (4) & ? & Forceps delivery, pneumonia, endometritis & Uterus, blood & None & Fatal \\
\hline 5 & & ? & Vaginal delivery, pneumonia, endometritis & Lochia, blood & Antiserum & Recovery \\
\hline 6 & & ? & $\begin{array}{l}\text { Caesarean section, pneumonia, } \\
\text { endometritis }\end{array}$ & Uterus, blood & None & Fatal \\
\hline 7 & & ? & $\begin{array}{l}\text { Caesarean section, pneumonia, } \\
\text { endometritis }\end{array}$ & Lochia, blood & None & Recovery \\
\hline 11 & & ? & Induced abortion, peritonitis, pneumonia & Uterus, blood & None & Fatal \\
\hline 12 & McCarthy et al (5) & 18 & Vaginal delivery, endometritis & Lochia & Antibiotics & Recovery \\
\hline 13 & Hutchison et al (7) & 27 & Vaginal delivery, meningitis, endometritis & $\begin{array}{l}\text { Uterus, vaginal swab, } \\
\text { CSF, blood }\end{array}$ & Antibiotics & Fatal \\
\hline
\end{tabular}

CSF Cerebrospinal fluid

TABLE 3

Pneumococcal peritonitis and endometritis in association with intrauterine contraceptive devices (IUCD)

\begin{tabular}{|c|c|c|c|c|c|c|c|}
\hline Case & Author & $\begin{array}{c}\text { Age } \\
\text { (years) }\end{array}$ & $\begin{array}{l}\text { IUCD } \\
\text { (duration) }\end{array}$ & Clinical circumstances & $\begin{array}{l}\text { Site of positive } \\
\text { pneumococcal } \\
\text { culture }\end{array}$ & Treatment & Outcome \\
\hline 1 & $\begin{array}{l}\text { Herbert and } \\
\text { Mortimer (8) }\end{array}$ & 32 & $\begin{array}{l}\text { Lippes loop } \\
\text { (2 years) }\end{array}$ & $\begin{array}{l}\text { Peritonitis, bilateral } \\
\text { salpingitis, recurrent } \\
\text { endometritis }\end{array}$ & $\begin{array}{l}\text { Peritoneal fluid, } \\
\text { blood, vaginal } \\
\text { discharge }\end{array}$ & $\begin{array}{l}\text { Laparotomy, antibiotics, } \\
\text { IUCD removal }\end{array}$ & Recovery \\
\hline 2 & $\begin{array}{l}\text { Gruer et al } \\
\text { (9) }\end{array}$ & 32 & $\begin{array}{l}\text { Gravigard } \\
(1.5 \text { years })\end{array}$ & Peritonitis & Blood & $\begin{array}{l}\text { Laparotomy, antibiotics, } \\
\text { IUCD removal }\end{array}$ & Recovery \\
\hline 4 & & 46 & $\begin{array}{l}\text { Dalcon } \\
\text { (4 years) }\end{array}$ & Peritonitis, salpingitis & $\begin{array}{l}\text { Blood, peritoneal } \\
\text { fluid }\end{array}$ & Laparotomy, antibiotics & Death \\
\hline 5 & $\begin{array}{l}\text { Ron-El et al } \\
\text { (10) }\end{array}$ & 39 & $\begin{array}{l}\text { Lippes loop } \\
\text { (2 years) }\end{array}$ & $\begin{array}{l}\text { Peritonitis, salpingitis, } \\
\text { pleural effusion }\end{array}$ & $\begin{array}{l}\text { Peritoneal and } \\
\text { pleural fluid }\end{array}$ & $\begin{array}{l}\text { Laparotomy, left } \\
\text { oophorectomy, } \\
\text { hysterectomy, antibiotics }\end{array}$ & Recovery \\
\hline
\end{tabular}

Strep pneumoniae was isolated from the cervix and blood of the patient described in the present report. The organism could have entered the blood via either respiratory or genital routes. The coexistence of $H$ influenzae in the cervical specimen might have supported the respiratory route, but the present patient had no symptoms of an upper respiratory tract infection, and a throat swab was not obtained. It is therefore much more likely that the genital route was the portal of entry. Disruption of the cervical mucosa by the tampon may have facilitated bloodstream invasion. Ascending infection probably led to peritonitis in this patient.
Direct orogenital transmission of Strep pneumoniae by oral sex was also considered. Simultaneous isolation of $H$ influenzae from the patient's cervical swab would support this. Against this, however, is the fact that the patient and her sexual partner had two different serotypes of pneumococcus. In addition, $H$ influenzae was not recovered from the partner's throat swab.

The role of the vaginal tampon is not clear. Tampons have been associated with Staphylococcus aureus in toxic shock syndrome (18), and in fact, this syndrome was considered in the initial differential diagnosis. It has been hypothesized in 
toxic shock syndrome that the tampon acts as a plug, allowing stasis or pooling of menstrual fluids, thus promoting multiplication of microorganisms (19). Other investigators have suggested that the physical and chemical constituents of tampons alter the growth environment by lowering magnesium ion content (20) and increasing $\mathrm{pCO}_{2}$ within the vagina (21). In addition, it has been demonstrated that the $\mathrm{pH}(6.9$ to 7.2), glucose, protein and calcium content of menstrual blood may provide a sufficient medium for expression of the toxic shock syndrome toxin (22). These factors could enhance the growth of Strep pneumoniae, which requires a neutral $\mathrm{pH}$ and higher carbon dioxide concentrations. The presence of blood products in the genital tract may account for the association of pneumococcal en-

ACKNOWLEDGEMENTS: The authors thank Dr VC Huang at the National Streptococcus Reference Centre, Laboratory Centre for Disease Control, Ottawa, Ontario for typing the isolates of Streptococcus pneumoniae.

\section{REFERENCES}

1. McCartney JE, Fraser J. Pneumococcal peritonitis. Br J Surg 1922;9:479-89.

2. Friedland JA, Harris MH. Primary pneumococcal peritonitis in a young adult. Am J Surg 1970;119:737-9.

3. McFarlaine AC, Hamra LK, Reiss-Levy E, Hansman D. Pneumococcal peritonitis in adolescent girls. Med J Aust 1979; 1:100-1.

4. Finland M, Dubin TD. Pneumococcic pneumonias complicating pregnancy and the puerperium. JAMA 1939;112:1027-32.

5. McCarthy VP, Cho CT. Endometritis and neonatal sepsis due to Streptococcus pneumoniae. Obstet Gynecol 1979;53S(Suppl 3):47-9.

6. Nuckols HH, Hertig AT. Pneumococcus infection of the genital tract in women. Am J Obstet Gynecol 1938;35:782-3.

7. Hutchison CPT, Kenney A, Eykyn S. Maternal and neonatal death due to pneumococcal infections. Obstet Gynecol 1984;63:130-1.

8. Herbert TJ, Mortimer PP. Recurrent pneumococcal peritonitis associated with IUCD. Br J Surg 1974;61:901-2.

9. Gruer LD, Colingham KE, Edwards CW.

Pneumococcal peritonitis associated with an IUCD. Lancet 1983;ii:667.

10. Ron-El R, Bukovsky I, Kharash J, Letko Y, Caspi E. Pneumococcal peritonitis with the presence of IUCD. Int J Gynecol Obstet 1985;23:339-41.

11. Goldman JA, Yeshaya A, Peleg D, Dekel A, Dicker D. Severe pneumococcal peritonitis complicating IUD: Case report and review of literature. Obstet Gynecol Surv 1986;41:672-4. dometritis and peritonitis with the post partum period. Finally, the tampon acting as a foreign body may have irritated the vaginal mucosa and facilitated the entry of organisms into the bloodstream.

An unusual case of pneumococcal endometritis with local peritonitis has been presented. To the authors' knowledge this is the only case in the literature describing pneumococcal endometritis with peritonitis and bacteremia in association with tampon use. Although the pneumococcus was not transmitted by oral sex, one should be cognizant of this mode of transmission in cases of pelvic inflammatory disease. Current therapy recommendations for pelvic inflammatory diseases provide adequate coverage for Strep pneumoniae (23).

12. Epstein M, Calia FM, Gabuzda GJ. Pneumococcal peritonitis in patient with postnecrotic cirrhosis. N Engl J Med 1968;278:69-73.

13. Larcher VF, Manolaki N, Vegnente A, Vergani D, Mowat AP. Spontaneous bacterial peritonitis in children with chronic liver disease: Clinical features and etiologic factors. J Pediatr 1985; 106:907-12.

14. Krensky AM, Ingelfinger JR, Grupe WE. Peritonitis in childhood nephrotic syndrome. Am J Dis Child 1982;136:732-6.

15. Julia A, Acebedo G, Jornet J, Zuazu J. Spontaneous pneumococcal peritonitis. Late infection after bone marrow transplant. N Engl J Med 1985;312:587.

16. Lipshutz B, Lowenburg H. Pneumococci and streptococci peritonitis. Report of 23 cases in infancy and childhood. JAMA 1926;86:99-106.

17. Cole WH. Pneumococcus peritonitis. Surgery 1937; 1:386-95.

18. See RH, Chow AW. Microbiology of toxic shock syndrome: A review. Rev Infect Dis 1989;11 (Suppl 1):S55-8.

19. Clayton AJ, Peacocke JE, Ewan PE. Toxic shock syndrome in Canada. Can Med Assoc J 1982; 126:776-9.

20. Mills JT, Parsonnet J, Tsai Y-C, Kendrick M, Hickman RK, Kass EH. Control of production of toxic shock syndrome toxin-1 (TSST-1) by magnesium ion. J Infect Dis 1985;151:1158-61.

21. Wagner G, Bohr Z, Wagner P, Peterson LN. Tampon-induced changes in vaginal oxygen and carbon dioxide tensions. Am J Obstet Gynecol 1984; 148:147-50.

22. Todd JK, Todd BH, Franco-Buff A, Smith CM, Lawellin DW. Influence of focal growth conditions on the pathogenesis of toxic shock syndrome. J Infect Dis 1987;155:673-81.

23. Peterson HB, Galaid EI, Zenilman JM. Pelvic inflammatory diseases: Review of treatment options. Rev Infect Dis 1990;12(Suppl 3):S656-64. 


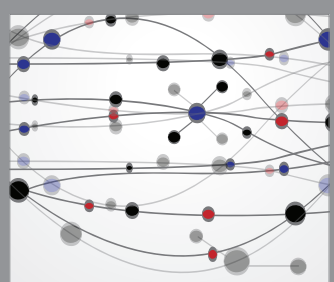

The Scientific World Journal
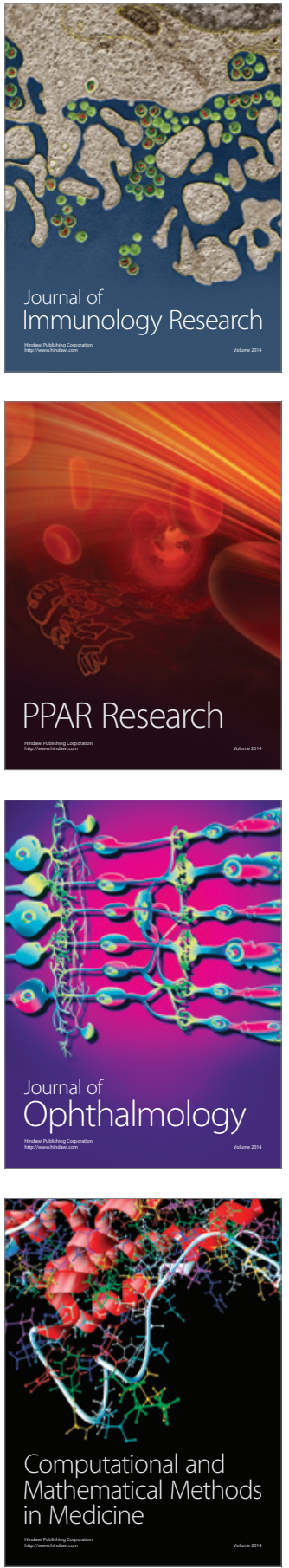

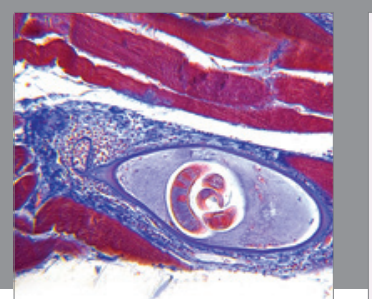

Gastroenterology Research and Practice

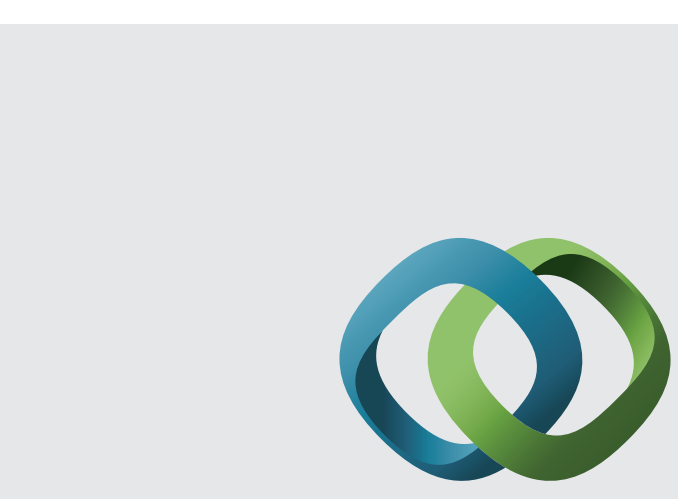

\section{Hindawi}

Submit your manuscripts at

http://www.hindawi.com
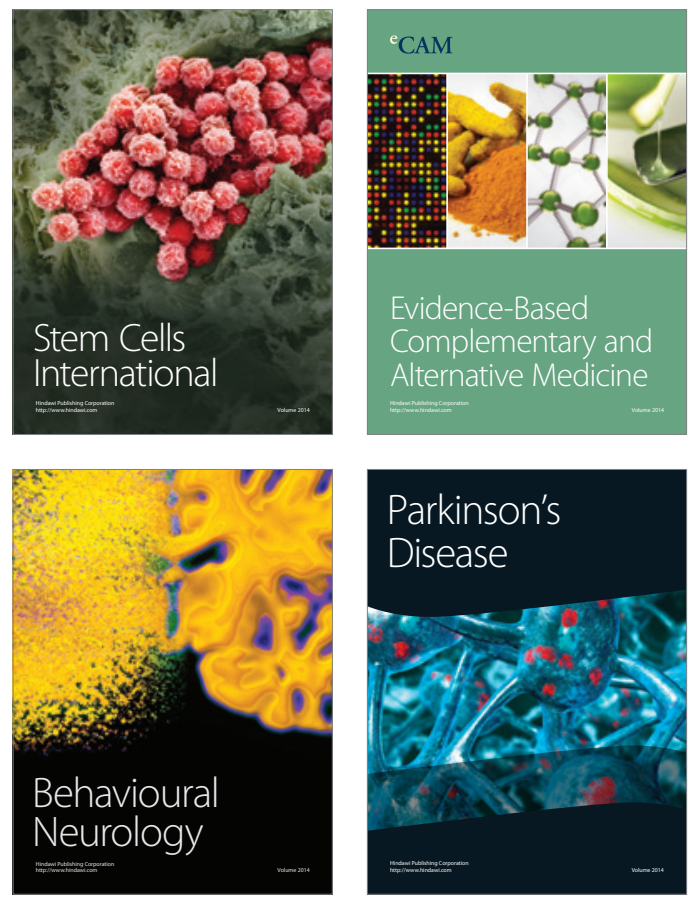
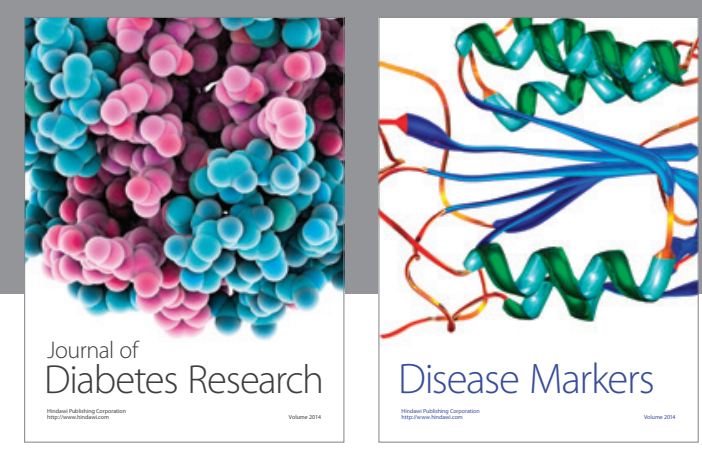

Disease Markers
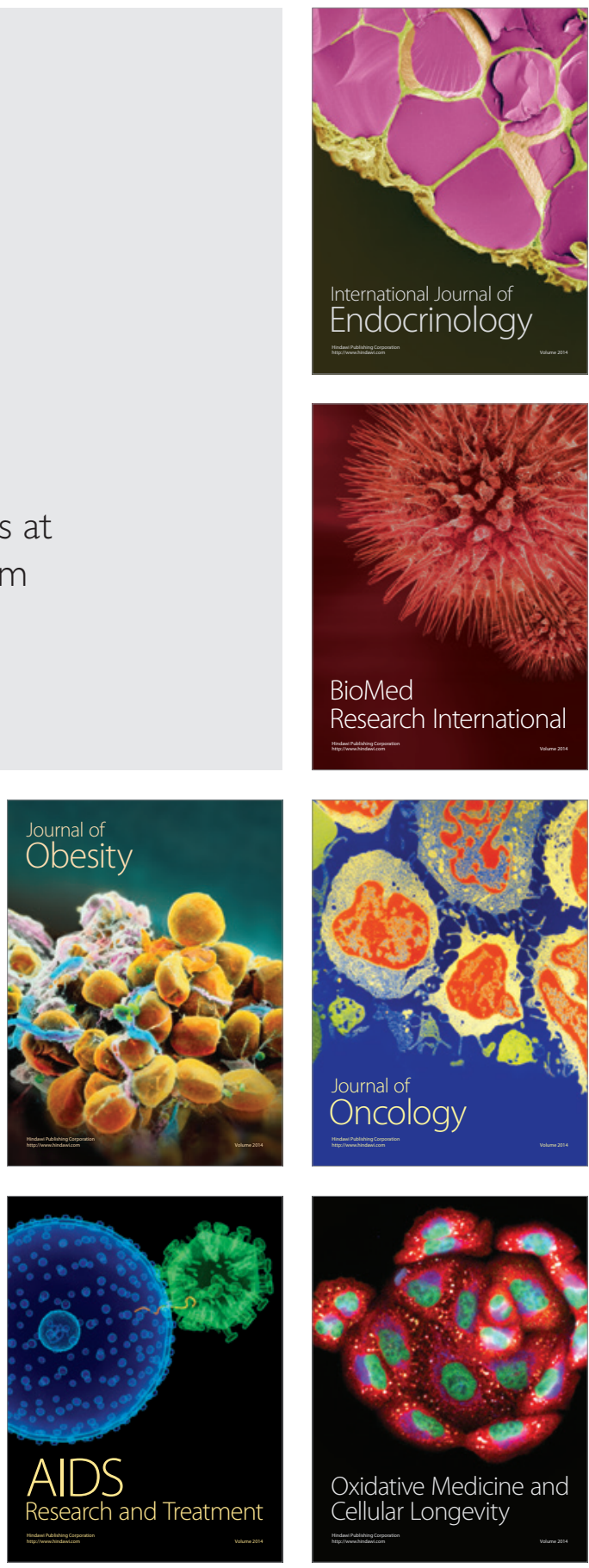